\title{
PENGEMBANGAN PROFESI BAGI GURU MADRASAH ALIYAH MELALUI DIKLAT PKG DAN PKB DI BDK JAKARTA
}

\author{
Umi Maisyaroh As \\ Balai Diklat Keagamaan Jakarta, Indonesia \\ setiawatimarina@gmail.com
}

\begin{abstract}
This study aims to determine the ability to understand the concept of professional development and the skills to compile the scientific publication of PKG and PKB Substantive Technical Training participants for Madrasah Aliyah teachers at the Jakarta Religious Education and Training Center in 2019. The method used in this research is a survey method with a qualitative approach. Data collection techniques used tests, rubrics and structured interviews. The data analysis technique used is descriptive qualitative with three stages, namely data reduction, display and verification. The results of this study indicate that, through PKG \& PKB Substantive Technical training for Madrasah Aliyah teachers can increase understanding of the concept of teacher professional development and improve teacher skills in compiling Scientific Publications.
\end{abstract}

Keywords: Development; PKG \& PKB; Teacher Professional.

\begin{abstract}
Abstrak
Penelitian ini bertujuan untuk mengetahui kemampuan pemahaman konsep pengembangan profesi dan keterampilan menyusun publikasi ilmaiah peserta Diklat Teknis Substantif PKG dan PKB bagi guru Madrasah Aliyah di Balai Diklat Keagamaan Jakarta tahun 2019. Metode yang digunakan dalam penelitian ini adalah metode survey dengan pendekatan kualitatif. Teknik pengumpulan data menggunakan tes, rubric dan wawancara terstruktur. Teknik analisis data yang digunakan deskriptif kualitatif dengan tiga tahapan yaitu reduksi data, display dan verifikasi. Hasil penelitian ini menunjukkan bahwa, melalui diklat Teknis Substantif PKG \& PKB bagi guru Madrasah Aliyah dapat meningkatkan pemahaman terhadap konsep pengembangan profesi guru dan meningkatkan keterampilan guru dalam menyusun Publikasi Ilmiah.
\end{abstract}

Kata Kunci: Diklat Jarak Jauh; kesulitan belajar; Penelitian Tindakan Kelas. 


\section{PENDAHULUAN}

Pendidikan dan pelatihan (Diklat) salah satu upaya peningkatan dan pengembangan kualitas sumber daya manusia, sehingga sampai saat ini Diklat menjadi program prioritas bagi setiap lembaga atau instansi yang konsen dengan penjaminan mutu sumber daya manusia. Hampir di setiap lini kebijakan, Diklat dianggap sebagai human capital yang akan memberikan kontribusi bagi peningkatan kualitas unit kerja/instansi. Pada sisi inilah, kemudian banyak ahli sumber daya manusia menganggap perlu adanya suatu upaya diklat sebagai bagain dari proses penjaminan mutu.

Pelaksanaan diklat pada dasarnya merupakan suatu proses pengalihan pengetahuan melalui pendidikan dan pelatihan untuk melihat apakah tujuan pendidikan dan pelatihan telah dicapai setelah. Undang-Undang Nomor 5 Tahun 2014 tentang Aparatur Sipil Negara menyatakan bahwa Aparatur Sipil Negara (ASN) sebagai profesi berlandaskan pada prinsip yang salah satunya adalah mempunyai kompetensi yang diperlukan sesuai dengan bidang tugas dan sebagai upaya mengembangkan kompetensi bagi ASN tersebut, dapat dilakukan salah satunya melalui kegiatan pendidikan dan pelatihan (UU No 5 Tahun 2014 pasal 3 dan 70).

Namun dalam kenyataannya masih banyak guru, khususnya guru Madrasah Aliyah yang masih mempunyai tingkat profesi kurang memadai/rendah, sehingga perlu ditingkatkan dengan melalui diklat. Indikasi rendahnya atau belum berkembangnya profesi antara lain lebih dari 50\% peserta diklat PKG dan PKB di BDK Jakarta tahun 2019 tertunda kenaikan pangkat/golongan yang disebabkan tidak terpenuhinya unsur pengembangan profesi (Data wawancara).

Perumusan Masalah

Dari uraian di atas, maka rumusan masalah dalam penelitian ini adalah: (1) Apakah dengan melalui diklat dapat meningkatkan pemahaman guru terhadap konsep pengembangan profesi dan (2) Apakah dengan melalui diklat dapat meningkatkan keterampilan guru dalam menyusun Publikasi Ilmiah.

\section{Tujuan}

1. Untuk mengetahui peningkatan pemahaman guru terhadap konsep pengembangan profesi

2. Untuk mengetahui peningkatan keterampilan guru dalam menyusun Publikasi Ilmiah.

\section{Manfaat Penelitian}

1. Sumbangan ilmiah/Referensi menyangkut pengembangan profesi guru Madrasah

2. Memberi masukan kepada Balai Diklat Keagamaan Jakarta yang telah menyelenggarakan Pendidikan dan Pelatihan (Diklat) PKG dan PKB. 
Penelitian ini didukung oleh beberapa teori, antara lain teori Diklat, teori PKG dan PKB. Menurut Dessler dalam Shahrooz (2013) mengatakan bahwa pelatihan dan pengembangan dimaknai sebagai sebuah proses yang memanfaatkan berbagai metode untuk menyediakan keterampilan yang dibutuhkan bagi pegawai dalam melaksanakan tugas dan pekerjaannya. Sedangkan fungsi pelatihan adalah untuk mengembangkan pengetahuan pegawai tentang budaya perusahaan, membantu pegawai dalam menggunakan teknologi baru, mamahami bagaimana bekerja secara efisien dan menekankan pada inovasi, kreativitas, dan pengetahuan, menjamin keselamatan sehingga dapat berkontribusi yang aman dan ketika para pegawai tersebut membutuhkan perubahan dan untuk menyiapkan pegawai dalam menerima dan bekerja secara efektif antar sesama (Noe, Hollenback, Gerhart, \& Wright dalam Ikramina, F., and Gustomo, A. (2014).

Diklat teknis substantif peningkatan kompetensi Penilaian Kinerja Guru (PKG) dan Pengembangan Keprofesionalan Berkelanjutan (PKB) yang diselenggarakan oleh Balai Diklat Keagamaan Jakarta adalah salah satu diklat yang diselenggarakan untuk meningkatkan pengetahuan guru-guru berkaitan dengan apa saja kebutuhan guru untuk memenuhi angka kreditnya. terutama pada aspek Pengembangan Diri.
Masih ditemukan guru-guru di lingkungan kementerian Agama di madrasah-madrasah, mengalami kesulitan dalam mengajukan angka kreditnya diantaranya karena pemahaman yang kurang tentang PKG dan PKB. Berdasarkan Peraturan Menteri Negara Pendayagunaan Aparatur Negara dan Reformasi Birokrasi nomor 16 tahun 2009 dikatakan bahwa "Jabatan fungsional guru adalah jabatan fungsional yang mempunyai ruang lingkup, tugas, tanggung jawab, dan wewenang untuk melakukan kegiatan mendidik, mengajar, membimbing, mengarahkan, melatih, menilai, dan mengevaluasi peserta didik pada pendidikan anak usia dini jalur pendidikan formal, pendidikan dasar, dan pendidikan menengah sesuai dengan peraturan perundang-undangan yang diduduki oleh Pegawai Negeri Sipil. (Permenneg PAN dan RB nomor 16 tahun 2009 Bab I Pasal 1 ayat 1 ).

Hasil penilaian kinerja guru yang dilakukan oleh Kepala Madrasah atau

tim penilai unitkerja merupakan dasar penetapan perolehan angka kredit guru dalam rangka pengembangan profesi guru. Jika penilaian ini dilaksanakan dengan obyektif, maka visi pemerintah untuk menghasilkan "insan yang cerdas komprehensif dan berdaya saing tinggi" lebih dapat dicapai. Pelaksanaan penilaian kinerja guru merupakan salah satu upaya peningkatan pengetahuan dan 
keterampilan guru untuk menunjukkan kinerja yang profesional di kelas.

Hasil penilaian kinerja guru selain sebagai input dalam penyusunan program Pengembangan Keprofesian Berkelanjutan (PKB) juga sebagai dasar dalam penetapan perolehan angka kredit guru dalam rangka pengembangan karir guru. Dalam rangka membangun profesi guru yang bermartabat, yakni tercapainya visi pendidikan nasional melalui proses pembelajaran yang berkualitas, maka perlu dilaksanakan peningkatan dan pengembangan kinerja guru secara berkelanjutan dan teratur. Hasil penilaian kinerja guru dapat juga dimanfaatkan untuk menyusun profil kinerja guru sebagai input dalam penyusunan program Pengembangan Keprofesian Berkelanjutan (PKB).

\section{Program Pengembangan}

Keprofesian Berkelanjutan merupakan adalah bagian penting dari proses pengembangan keprofesian guru yang merupakan tanggungjawab guru secara individu sebagai masyarakat. Oleh karena itu, kegiatan Pengembangan Keprofesian Berkelanjutan harus mendukung kebutuhan individu dalam meningkatkan praktik keprofesian guru dan fokus pada pemenuhan dan pengembangan kompetensi guru untuk mendukung pengembangan karirnya.

Diklat mempunyai arti proses belajar mengajar dalam rangka meningkatkan kemampuan dalam melaksanakan tugas dan jabatan tertentu. Diklat yang diikuti merupakan jenis diklat yang dilaksanakan berdasarkan kebutuhan seseorang yang memegang jabatan atau pelaksana pekerjaan tiap jenis jabatan atau unit organisasi untuk meningkatkan pengetahuan, keterampilan dan sikap dalam melaksanakan tugas secara efektif dan efisien. Pelatihan atau training merupakan bagian dari suatu proses pendidikan yang bertujuan untuk meningkatkan kemampuan atauketerampilan khusus karyawan atau isntitusi. Pelatihan adalah suatu proses yang akan menghasilkan suatu perubahan perilaku bagi karyawan, Notoatmojdjo (2009:23).

Pelatihan adalah proses belajar mengajar dengan menggunakan teknik

dan metode tertentu guna meningkatkan kemampuan kerja pegawai/karyawan. Pelatihan lebih banyak dilakukan untuk tingkat keryawan supervisor ke bawah, karena setiap pelatihan dimaksudkan untuk dapat meningkatkan kemampuan operasional mesin-mesin (peralatan produksi) yang ada dalam perusahaan, (Nasution, 2000:56)

Dalam Permenneg PAN dan RB nomor 16 tahun 2009 tentang jabatan Fungsional Guru dan Angka Kreditnya, dalam Bab I Pasal 1 ayat 8 disebutkan: "Penilaian kinerja Guru adalah penilaian dari tiap butir kegiatan tugas utama Guru dalam rangka pembinaan karier kepangkatan dan jabatannya". Selain itu, Permenneg PAN dan RB Nomor 16 Tahun 2009 juga menyatakan bahwa 
penilaian kinerja guru adalah penilaian yang dilakukan terhadap setiap butir kegiatan tugas utama guru dalam rangka pembinaan karir, kepangkatan, dan jabatannya. Pelaksanaan tugas utama guru tidak dapat dipisahkan dari kemampuan seorang guru dalam penguasaan dan penerapan kompetensinya.

Sistem penilaian kinerja guru adalah sebuah sistem pengelolaan kinerja berbasis guru yang didesain untuk mengevaluasi tingkatan kinerja guru secara individu dalam rangka mencapai kinerja sekolah secara maksimal yang berdampak pada peningkatan prestasi peserta didik. Ini merupakan bentuk penilaian yang sangat penting untuk mengukur kinerja guru dalam melaksanakan pekerjaannya sebagai bentuk akuntabilitas sekolah.

Pengembangan keprofesian berkelanjutan mencakup kegiatan perencanaan, pelaksanaan, evaluasi, dan refleksi yang didesain untuk meningkatkan karakteristik, pengetahuan, pemahaman, dan keterampilan sebagaimana digambarkan pada diagram berikut ini (diadopsi dari Center for Continuous Professional Development (CPD). University of Cincinnati Academic Health Center. (http://webcentral.uc.edu/cpd_online2).

Berdasarkan Peraturan Menteri Pendidikan Nasional Nomor 16 Tahun
2007 tentang Standar Kualifikasi Akademik dan Kompetensi Guru terdapat 4 (empat) kompetensi yang harus dimiliki guru yaitu kompetensi pedagogik, kepribadian, sosial, dan profesional dengan 14 (empat belas) subkompetensi sebagaimana yang telah dirumuskan oleh Badan Standar Nasional Pendidikan (BSNP). Sedangkan Peraturan Menteri Pendidikan Nasional Nomor 27 Tahun 2008 tentang Standar Kualifikasi Akademik dan Kompetensi Konselor menjelaskan bahwa seorang guru BK/Konselor juga harus memiliki 4 (empat) kompetensi (pedagogik, keperibadian, sosial, dan profesional) dengan 17 sub-kompetensi.

Melalui siklus evaluasi, refleksi pengalaman belajar, perencanaan dan implementasi kegiatan pengembangan keprofesian guru secara berkelanjutan, maka diharapkan guru akan mampu mempercepat pengembangan kompetensi pedagogik, profesional, sosial, dan kepribadian untuk kemajuan karirnya. Menurut Permenneg PAN dan RB Nomor 16 Tahun 2009, unsur kegiatan pengembangan keprofesian berkelanjutan yang saat ini disebut Pengembangan Profesi Guru meliputi: Pengembangan Diri, Publikasi Ilmiah, dan Karya Inovatif.

Tujuan umum dari kegiatan pengembangan keprofesian berkelanjutan pengembangan profesi guru adalah untuk meningkatkan kualitas layanan pendidikan di sekolah 
dalam rangka meningkatkan mutu pendidikan.

Dalam penelitian Mujiyanto Paulus (2015 : 12) seorang widyaiswara pada LPMP Jawa Tengah, dikatakan bahwa guru-guru sekolah dasar di kecamatan Bener kabupaten Purworejo Provinsi Jawa Tengah memiliki cukup pemahaman tentang konsep PKG, memiliki keterampilan melaksanakan PKG dengan baik, sikap terhadap PKG juga baik namun responden menganggap bahwa PKG cukup untuk kegiatan meningkatkan profesionalisme. Penelitian yang melibatkan populasi 367 orang dan sampel sebanyak 30 orang ini menarik peneliti untuk membandingkannya dengan peserta diklat PKG dan PKB yang dilaksanakan oleh Balai Diklat Keagamaan Jakarta.

Tulisan Ilmiah Populer Karya ilmiah populer adalah tulisan yang dipublikasikan di media massa (koran, majalah, atau Media online yang mempunyai alamat website resmi bukan Blog). Karya ilmiah populer dalam kaitan dengan upaya pengembangan profesi ini merupakan kelompok tulisan yang lebih banyak mengandung isi pengetahuan, berupa ide, atau gagasan pengalaman penulis yang menyangkut bidang pendidikan pada satuan pendidikan penulis bersangkutan

\section{METODE}

Penelitian ini dilakukan di Balai Diklat Keagamaan Jakarta dengan jumlah responden sebanyak 40 orang, yang berasal dari tiga propinsi, yaitu: propinsi DKI Jakarta sebanyak 15 orang, Propinsi Banten 20 orang dan Propinsi Kalimantan Barat 5 orang. Metode yang digunakan dalam penelitian ini adalah survey dan deskriptif kualitatif dengan menggunakan insrumen tes, rubric dan wawancara terstruktur.

Penelitian ini dilakukan untuk mengungkap fakta yang terjadi di kalangan guru Madrasah Aliyah tentang kemampuan secara konsep dan keterampilan dalam menyusun publikasi ilmiah sebagai bagian dari persyaratan pengembangan profesi. Sasaran penelitian terdiri dari 2 aspek, yaitu aspek kemampuan memahami konsep dasar pengembangan profesi dan keterampilan dalam menyusun publikasi ilmiah, khususnya publikasi ilmiah dalam bentuk artikel ilmiah populer.

Data tentang kemampuan memahami konsep dasar pengembangan profesi diperoleh melalui tes. Sedangkan data tentang keterampilan dalam menyusun publikasi ilmiah, khususnya publikasi ilmiah dalam bentuk artikel ilmiah populer diperoleh dengan rubrik berdasarkan produk yang dihasilkan.

Data hasil penelitian diolah dengan menggunakan 2 teknik atau pendekatan. Untuk data pemahaman konsep dasar pengembangan profesi menggunakan rerata. Sedangkan data keterampilan menyusun publikasi 
ilmiah menggunakan deskriptif kualitatif.

\section{HASIL DAN PEMBAHASAN}

1. Pemahaman Konsep

Pengembangan Profesi

Pemahamaan konsep pengembangan profesi yang dimaksud dalam penelitian ini adalah pemahaman guru selaku peserta dikat PKG dan PKB dalam aspek penyusunan proposal penelitian, penyusunan publikasi ilmiah jenis artikel ilmiah hasil penelitian, dan penyusunan artikel ilmiah populer. Hasil penelitian dapat dilihat pada gambar berikut:

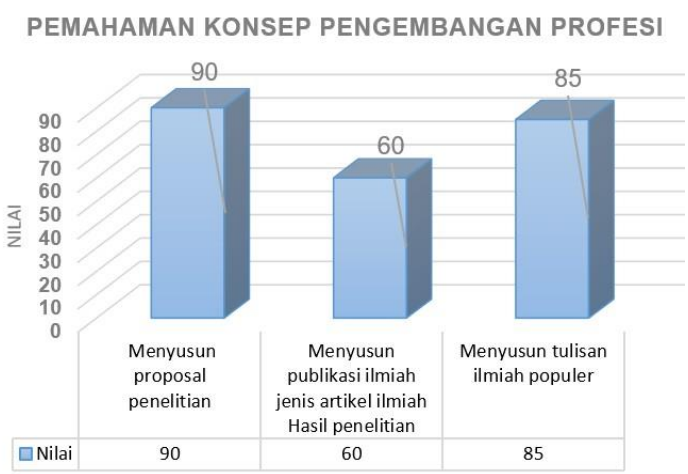

Berdasarkan gambar 1 di atas, diperoleh gambaran bahwa kemampuan guru dalam konsep pengembangan profesi, khususnya dalam menyusun karya tulis ilmiah sangat bervariasi.

Dari tiga aspek yang diukur, diperoleh bahwa sudah lebih memahami bagaimana cara meyusun proposal Penelitian dengan ditandai adanya skor 90 ( sangat baik). Guru sudah sangat memahami secara teoritis bagaimana menyusun latar belakang, identifikasi, dan perumusan masalah, tujuan dan manfaat dalam pendahuluan. Guru juga sudah sangat memahami bagaimana cara merangkai teori sehingga menjadi sebuah teori baru dalam bagian kajian teori dan sangat memahami metodologi apa dan bagaimana yang harus digunakan dan dituliskan dalam bagian metodologi penelitian.

Dalam pemahaman bagaimana cara

menyusun laporan hasil penelitian secara umum guru sudah baik, namun dalam meyusun laporaan hasil penelitian menjadi sebuah artikel yang layak dimuat dijurnal masih banyak yang belum memahami secara utuh. Sehinnga hasil penelitian menunjukan bahwa pemahamn guru bagaimana menyusun artikel yang berasal dari laporan hasil penelitian kurang baik dengan sekor 60 .

Sedangkan satu aspek pemahaman guru dalam menyusun tuliasan atau artikel ilmiah populer sudah baik dengan sekor 85 . Pemahaman guru bagaimana menyusun artikel ilmiah populer tersebut didukung oleh seringnya mengikuti pelatihan menyusun karangan.

Secara umum dapat dinyatakan bahwa guru selaku peserta diklat PKG dan PKB sudah mempunyai pemahaman yang baik bagaimana cara menyusun proposal penelitian, menyusun publikasi ilmiah jenis artikel 
ilmiah hasil penelitian dan menyusun tulisan ilmiah populer. Hal ini didukung oleh pengamatan dan aktivitas berdiskusi dan Tanya jawab selama diklat berlangsung, serta didukung oleh hasil posttest yang dilakukan pada akhir pembelajaran.

\section{Keterampilan Guru Dalam Menyusun} Publikasi Ilmiah

Keterampilan guru dalam menyusun publikasi ilmih yang dimaksud dalam penelitian ini adalah keterampilan guru selaku peserta dikat PKG dab PKB dalam aspek penyusunan proposal penelitian, penyusunan publikasi ilmiah jenis artikel ilmiah hasil penelitian, dan penyusunan artikel ilmiah populer.

Hasil penelitian dapat dilihat pada gambar berikut:

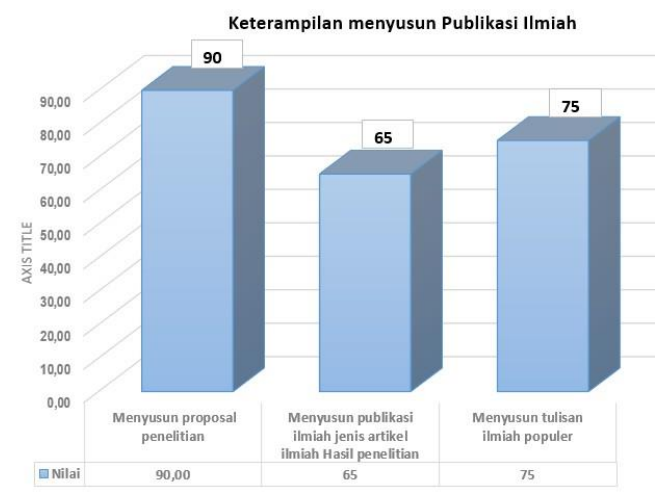

Berdasarkan gambar 2 di atas, diperoleh gambaran bahwa keterampilan guru dalam menyusun karya tulis ilmiah masih sangat memprihatinkan.

Dari tiga aspek yang diukur, diperoleh gambaran bahwa guru hanya memiliki keterampilan dalam menyusun proposal penelitian yang terkatogori sangat baik dengan sekor 90. Terampilnya guru dalam menyusun proposal disebabkan oleh seringnya mengikuti kegiatan pengembangan diri yang berbasis pengembangan profesi guru. Mulai dari workshop, seminar, diskusi di MGMP sampai dengan mengikuti berbagai pelatihan. Proses atau kegiatan tersebut hanya sekedar mempelajari dan memahami cara serta menyusun proposal, sehingga menghasilkan sebuah proposal sebagai tagihan atau produk. Hasilnya adalah hampir semua guru terampil dalam menyusun proposal penelitian.

Namun proposal tersebut selalukandas ketika ditindaklanjuti ke tataran penelitian atau penyusunan hasil penelitian. Sehingga tepat jika dikatakan bahwa keterampilan dalam menyusuan publikasi ilmiah dalam bentuk artikel ilmiah hasil penelitian sangat rendah dengan sekor 65 .

Dari kondisi di atas, menyebabkan guru mempunyai keterampilan yang sangat rendah dalam menyusun laporan hasil penelitian yang akhirnya berdampak pada rendahnya keterampilan dalam menindak lanjuti hasil sebuah penelitian menjadi sebuah artikel hasil penelitian yang siap dimuat dalam berbagai junal ilmiah instansi yang tidak terakreditasi maupun jurnal nasional terakreditasi.

Selain rendahnya keterampilan guru dalam menyusun artikel ilmiah hasil penelitian, guru juga masih 
memiliki keterampilan yang terkategori cukup dalam menyusun atau membuat artikel ilmiah populer (non penelitian) dengan sekor 75. Belum maksimalnya keterampilan guru dalam menyusun artikel ilmiah populer lebih disebabkan oleh karena belum terbiasa dan belum maksimal memanfaatkan momenmomen atau peristiwa tertentu yang terjadi di lingkungan sekitar menjadi sebuah informasi ilmiah. Penyebab lain adalah masih minimnya media atau majalah ilmiah yang siap memuat tulisan-tulisan atau artikel yang bersifat populer atau kejadian khsusus yang sedang menjadi trend diperbincangkan di masyarakat luas.

Secara umum dapat dinyatakan bahwa guru selaku peserta diklat PKG dan PKB belum mempunyai keterampilan yang baik dalam menyusun sebuah artikel dalam pengembangan profesi berkelanjutan, khususnya dalam bentuk, penyusunan publikasi ilmiah jenis artikel ilmiah hasil penelitian dan menyusun tulisan ilmiah populer. Hal ini didukung oleh pengamatan dan fakta bahwa masih banyak guru yang berhenti kenaikan karier kepangkatan dan jabatan di golongan IV/a.

\section{KESIMPULAN}

Berdasarkan hasil penelitian dan pembahasan pada penelitian ini, maka dapat disimpulkan bahwa:

1. Melalui diklat Teknis Substantif PKG \& PKB dapat meningkatkan pemahaman terhadap konsep pengembangan profesi guru, khususnya pemahaman tentang penyusunan proposal penelitian, namun belum maksimal dalam memahami cara menyusun artikel ilmiah

2. Meningkatkan keterampilan guru dalam menyusun Publikasi Ilmiah, khususnya penyusunan proposal dan belum terampil dalam menyusun artikel secara maksimal baik hasil penelitian maupun ilmiah populer.

\section{DAFTAR PUSTAKA}

Afandi, M. (2019). Evaluasi Implementasi Pengembangan Keprofesian Berkelanjutan (Pkb) Bagi Guru Pjok Smp Dalam Meningkatkan Keprofesionalan Di Kota Tebing Tinggi (Doctoral dissertation, UNIMED).

Fattah, Nanang. 2004. Landasan Manajemen Pendidikan. Bandung: Rosdakarya. Gunawan, Rahmat Dwi. 2017. Studi tentang Kompetensi Widyaiswara dalam Mengelola 
Pembelajaran di Lembaga Penjaminan Mutu Pendidikan Daerah Istimewa Yogyakarta. E-Jurnal Prodi Teknologi Pendidikan Vol.VI Nomor 5 Tahun 2017.

Juniardi, Y. (2019). Kesulitan Guru Sekolah Dasar dalam Membuat Karya Tulis Ilmiah. In Prosiding Seminar (Vol. 1, No. 1, pp. 1-7).

Meitaningrum, Dhita Ayu, Imam Harjanto dan Siswidiyanto. 2000. Efektifitas Pendidikan dan Pelatihan dalam meningkatkan Kinerja Pegawai (Studi pada Badan Kepegawaian Daerah Kabupaten Malang), Jurnal Administrasi Publik, Fakultas Ilmu Administrasi, Universitas Brawijaya Malang.

Pratama, A. L. (2018). Pemberdayaan pendidik (studi kasus pengembangan keprofesian berkelanjutan guru di SMK $\mathrm{N}$ Seni). Jurnal Akuntabilitas Manajemen Pendidikan, 6(1), 90-104.

Puspitaningrum, I., \& Hartiti, T. (2017). Peningkatan kualitas personal Dan profesional perawat melalui Pengembangan keprofesian Berkelanjutan (PKB). deepublish.

Rezeki, Sri, Murniati AR, dan Cut Zahri Harun, 2015. Manajemen Pembelajaran Pendidikan dan Pelatihan Prajabatan pada BKPP Aceh. Jurnal Administrasi Pendidikan Pascasarjana Universitas Syiah Kuala.

Sedarmayanti. 2009. Manajemen Sumber Daya Manusia: Reformasi Birokrasi dan Manajemen PNS. Yogyakarta: Aditama.

Sumantri, Rita Fahdila. 2012 Kompetensi Pengelolaan Pembelajaran, Kecerdasan Interpersonal, Komitmen dan Kepuasan Kerja Guru SMK. Jurnal Ilmu Pendidikan, Jilid 18, Nomor 1, Juni 2012. Universitas Negeri Malang, pada situs http://journal.um.ac.id/index.php/jip/article/view/3380(diunduh pada 11 Mei 2018.

Yaqin, H. (2011). Administrasi dan Manajamen Pendidikan. Banjarmasin: IAIN Antasari press Banjarmasin.. 